\title{
National Webinar on Philosophy and Psychological Review of Thinking Disposition
}

\author{
Yayan Eryk Setiawan ${ }^{1, a)}$, and Triwilujeng Ayuningtyas ${ }^{2}$ \\ ${ }^{1}$ Program S1 Pendidikan Matematika, Universitas Islam Malang, Malang, Jawa Timur, Indonesia \\ 2Program S1 Pendidikan Ekonomi, STKIP PGRI Lumajang, Lumajang, Jawa Timur, Indonesia \\ a)Corresponding author: yayaneryksetiawan@unisma.ac.id
}

\begin{abstract}
In addition to the ability to think, students need a thinking disposition to succeed in learning. However, the results of preliminary research indicate that the knowledge of prospective teachers, teachers, and lecturers is still low on thinking dispositions. Therefore, this problem can be solved by conducting a national webinar on dispositions of thinking. Thus, the purpose of this service is to provide participants with an understanding of the philosophical and psychological dispositions of thinking. This service method is in the form of a national webinar, which is a seminar held online. This webinar activity is divided into three stages, namely the material presentation stage, the question and answer stage, and the community service evaluation stage. The results of this community service evaluation show that the percentage of the results of filling out the questionnaire is $81 \%$ which means that it is in the very high category. This means that this national webinar activity was very successful in understanding the participants towards a philosophical and psychological review of thinking dispositions. This success is supported by the availability of material, internet signals, and the ability of the presenters to convey the material. Apart from that, there are also inhibiting factors in this seminar activity, namely inadequate material delivery time, signal constraints, and too many presenters.
\end{abstract}

Key words: Community Service, Thinking disposition, Webinars.

\section{INTRODUCTION}

Not only thinking ability but also thinking skills are important to be taught to students. This thinking skill is often referred to as thinking disposition (Perkins et al., 1993; Ron, 2001; Tishman et al., 1993; Tishman \& Andrade, 1995). The results show that this thinking disposition affects students' success in learning (Almerino et al., 2019; Atabaki et al., 2015; Ron, 2001). For example, research results show that beliefs significantly affect students' mathematical dispositions (Almerino et al., 2019). The results also show that one must have the intellectual curiosity to succeed in learning (Ron, 2001; Tishman et al., 1993; Tishman \& Andrade, 1995). The results also show that students who have high flexibility also have high accuracy (Hästö et al., 2019). The results also show that dispositions affect the way students solve problems (Setiawan, 2020b, 2020e, 2020a; Setiawan et al., 2020). Thus it can be said that the disposition of thinking is also important to be taught to students.

However, the results of the preliminary study showed that the knowledge of 84 respondents consisting of 70 prospective mathematics teachers, 10 teachers, and 6 lecturers showed that knowledge about thinking disposition was still very low, namely $38.45 \%$ (Setiawan, 2021). This preliminary research was conducted by asking the 84 respondents to fill out a questionnaire consisting of 11 questions using the choices: very knowing, little knowing, not knowing, and very not knowing. Each of these choices was given a score of 4, 3, 2, and 1 . An example of one of the questions in the questionnaire is whether you know about the difference between thinking disposition and thinking ability. The results of filling out this question obtained $41.07 \%$. This means that respondents' knowledge about the difference between thinking disposition and thinking ability is still low. Preliminary research results also show that $50 \%$ of respondents do not know about thinking disposition.

One way that can be used to overcome the respondent's low knowledge about thinking dispositions is to hold a national webinar on thinking dispositions. This webinar activity is an 
online seminar activity. The advantages of this webinar activity are that it has a wide range, the costs incurred are more affordable than face-to-face seminars, and all activities are easy to record, so they can be played back. While the drawback of this webinar activity is that it relies on an internet connection. If the connection is bad, it can interfere with the running of the webinar. Therefore, every webinar participant must provide an adequate internet network for webinar activities. Based on this, this service activity is in the form of a national webinar with the theme of thinking disposition. The main purpose of this webinar activity is to provide understanding for webinar participants to know things related to thinking dispositions. Therefore, the expected result of this webinar activity is that participants have a good understanding of thinking dispositions.

\section{METHOD}

This service activity is a national webinar activity on thinking disposition. This service was held on December 27, 2020. This activity aims to provide webinar participants with an understanding of the philosophical and psychological review of thinking dispositions. This service activity in the form of a webinar was carried out at the Islamic University of Malang in collaboration with the student association of the mathematics education study program. Himaprodi's role as a partner is as the implementing committee for this national webinar activity.

This webinar activity generally consists of three stages, namely material presentation, question and answer, and evaluation of webinar activities (see Figure 1 in the Attachment). The first stage is the presentation of the material. The time given by the committee to presenters in delivering their material is about 20 minutes. The material presented by the devotees in this webinar consists of: the origin of thinking dispositions, philosophical reviews of thinking dispositions, psychological reviews of thinking dispositions, definitions of thinking dispositions in various contexts, relationships and differences between thinking dispositions and thinking abilities, other terms of thinking dispositions, definitions of disposition of thinking from a philosophical perspective and a psychological perspective, and the difference between thinking disposition and habit of thinking. These materials can be seen in the book entitled Thinking Disposition which was written by the devotee himself (Setiawan, 2020c).

The second stage is question and answer. This question and answer session lasted about 30 minutes. The moderator provides an opportunity for participants to ask questions to the presenters. Then the moderator allows the presenters to provide responses or answers to questions posed by participants. In this activity, there is also a discussion between the participants and the presenters, so that participants can understand the answers to the questions given to the presenters.

The third stage is the evaluation of the implementation of the webinar activity. The evaluation of this webinar activity was carried out by asking participants to voluntarily fill out a prepared questionnaire. Filling out the questionnaire is done using Google Forms. This service evaluation questionnaire is adjusted to the webinar stage, where the questionnaire generally contains: (a) the content of the material, (b) the presentation of the material, and (c) question and answer activities. Each question in the questionnaire uses the choices strongly disagree (SD), disagree $(D)$, neutral $(N)$, agree $(A)$, and strongly agree (SA). Each of these choices was given a score of $5,4,3,2$, and 1.15 questionnaire items had to be answered by the participants. From the total score obtained, the success of this webinar will be categorized using very low, low, medium, high, and very high intervals which can be seen in Table 1 (see Attachment).

From Table 1, it can be seen that the success limit of this webinar is in the high category. If the percentage of the total score is in the high or very high category, then this national webinar is a success. However, if the percentage of the total score is in the medium, low, or very low category, then this national webinar has not succeeded in providing an understanding of the thinking disposition of the webinar participants. 


\section{RESULTS}

This national webinar activity has the theme "Emergency Remote Learning Student's Cognitive Processes and Attitude" (see Figure 2 in the Attachment). This webinar activity uses the Zoom Meeting application. This national webinar was attended by 128 participants consisting of students, teachers, and lecturers. This national webinar activity consists of 5 presenters, one of whom is a servant. This national webinar activity is divided into two sessions, the first session is filled by 3 presenters and the second session is filled by 2 presenters. The devotee filled this activity in the second session with the title of a philosophical and psychological review of thinking disposition. In this article, we will describe the results of the dedication carried out by the servants.

Each session of this service activity consists of three stages. The first stage is the delivery of material by the presenter. Each presenter has the opportunity to present his material within 20 minutes. Before starting to deliver the material, the servant first checked the clarity of the voice. This is done to ensure that the sound is heard clearly. After the voice is heard clearly by the webinar participants, the servant begins to deliver the material. Submission of material is done using power points that discuss philosophical and psychological reviews of thinking dispositions. The activity of delivering this material can be seen in Figure 3 (see Attachment). The stage of presentation of this material has constraints in terms of time. 20 minutes is not enough time to convey all the material. Therefore, several materials are briefly presented to the participants. As a result, participants must learn independently from the material provided. After the presentation stage of this material is complete, then proceed to the second stage, namely the question and answer stage.

The second stage of this webinar activity is a question and answer session. The moderator provides an opportunity for participants to ask questions to the presenters. Questions can be made by writing in the chat menu from the zoom meeting or can directly ask by communicating with the presenter. The activity at the question and answer stage lasted 30 minutes. The obstacle in this question session is the time that does not allow to answer questions. The way to overcome this obstacle is to provide important conclusions about webinar activities. After the question and answer activity is completed, then proceed to the service evaluation stage.

The third stage of this webinar activity is service evaluation. This service evaluation aims to find out how the participants respond to this national webinar activity. This service evaluation is done by asking participants to fill out a service evaluation questionnaire. Of the 128 webinar participants, 34 participants voluntarily filled out the questionnaire. This questionnaire consists of 15 statements that must be filled out by participants. The results of filling out the questionnaire will determine the score per each statement and the total score from filling out the questionnaire. The results of filling out the questionnaire can be seen in Table 2 (see Attachment). From Table 2 it can be seen that the total score from the results of filling out the questionnaire is 2,071 . The percentage of the results of filling out the questionnaire is included in the very high category. This means that this national webinar on thinking dispositions is very successful in providing an understanding of philosophical and psychological reviews of thinking dispositions.

\section{DISCUSSION}

This community service activity contributes to providing understanding to the webinar participants about the philosophical and psychological review of thinking dispositions. This material is important to be understood by prospective teacher students, teachers, or lecturers to be able to teach thinking dispositions to students or students. Thus, it is hoped that students and students will not only learn about thinking skills but also about thinking dispositions. The results of the dedication show that this webinar activity has been successful in providing understanding 
to participants about thinking dispositions. This can be seen from the results of the service evaluation which shows that this webinar activity is very successful.

The success of this activity cannot be separated from the supporting factors. In general, the factors that support the success of this webinar are: (a) the availability of good and easy-tounderstand webinar material, (b) the availability of internet signals, and (c) the adequacy of the presenter's ability to deliver the material. Factors that support the success of the training in more detail can be seen in Table 2 (see Attachment). These three supporting factors are by the results of previous dedications which show that training and seminar materials must be well prepared, this is because these materials can make it easier for participants to understand the material (Sutrisno \& Zuhri, 2019) and add insight to participants (Hia et al., 2016). The results of the service also show that the delivery of clear and easy-to-understand material can increase the enthusiasm of the participants in attending the seminar (Susantini et al., 2015). The results of the service also show that one of the factors that support the success of the training or seminar is that the presenters are very knowledgeable about the material and can present the material well (Setiawan, 2020d, 2020f). Therefore, the supporting factors in the form of materials, internet signals, and the ability of the presenters in delivering the material should be a concern for every presenter in conducting training activities, seminars, or webinars.

In addition, there are also factors inhibiting success. The inhibiting factors for the success of this training were inadequate time allocation for material delivery, internet signal constraints, and too many presenters. This is supported by the opinion of the participants, namely that there should be sufficient internet for the committee and presenters and there is no need for many presenters so that there is more time to explain the material. Therefore, each of these problems can be overcome by the presenters preparing the material properly and completely, the signal provided is sufficient, and the presenters are sufficient, namely 2 or 3 presenters. It is hoped that the next webinar will run smoothly. In addition, several participants also gave suggestions for the next webinar activity.

\section{CONCLUSIONS AND RECOMMENDATIONS}

From the results of the service evaluation, it can be concluded that this webinar was very successful in providing participants' understanding of the philosophical and psychological review of thinking dispositions. This success can be seen from the results of the service evaluation of $81 \%$ which means it is in the very high category. The success of this webinar activity is supported by the availability of systematic materials, internet signals, and the delivery of material in a smooth and easy-to-understand manner. The devotee recommends the next webinar activity by discussing thinking disposition learning, thinking disposition assessment, thinking disposition research, and developing thinking disposition-based tools.

\section{ACKNOWLEDGMENTS}

We express our gratitude to Allah Subhanahu Wa Ta'ala, because for the facilities provided so that this Community Service can run smoothly. Thanks to both parents who have prayed for, guided, and motivated the author to achieve his goals. Thanks are conveyed to the Islamic University of Malang, especially students of the mathematics education study program as partners in this service activity who have facilitated the implementation of this service activity. Thank you to the team of editors and reviewers who have assessed and published this scientific work. May Allah Subhanahu Wa Ta'ala reward you with the good you deserve. Amen.

\section{REFERENCES}

Almerino, P. M., Etcuban, J. O., Jose, C. G. De, \& Almerino, J. G. F. (2019). Students' Affective 
Belief as the Component in Mathematical Disposition. International Electronic Journal of Mathematics Education, 14(3), 475-487. https://doi.org/https://doi.org/10.29333/iejme/ 5750

Atabaki, A. M. S., Keshtiaray, N., \& Yarmohammadian, M. H. (2015). Scrutiny of critical thinking concept. International Education Studies, 8(3), 93-102. https://doi.org/10.5539/ies. v8n3p93

Hästö, P., Palkki, R., Tuomela, D., \& Star, J. R. (2019). Relati ionship between b mathem matical fle exibility and suc ccess in nation nal exam minations s. European Journal of Science and Mathematics Education, 7(1), 1-13.

Hia, Y. D., Sumarni, \& Armiati. (2016). Pelatihan Metode Pembelajaran Inovatif untuk Meningkatkan Profesionalisme Guru SMA. Jurnal Pelangi, 8(2), 243-249. http://ejournal.stkip-pgri-sumbar.ac.id/index.php/pelangi/article/download/1206/pdf

Perkins, D. N., Jay, E., \& Tishman, S. (1993). Beyond Abilities: A Dispositional Theory of Thinking. Merril-Palmer Quarterly, 39(1), 1-21.

Ron, S. (2001). From IQ to IC: A Dispositional View of Intelligence. Roeper Riview, 23(3), 1-23.

Setiawan, Y. E. (2020a). Analisis Kemampuan Siswa dalam Pembuktian Kesebangunan Dua Segitiga. Al-Khwarizmi: Jurnal Pendidikan Matematika Dan Ilmu Pengetahuan Alam, 8(1), 23-38. https://doi.org/http://dx.doi.org/10.24256/jpmipa.v8i1.800

Setiawan, Y. E. (2020b). Analisis Kesalahan Siswa dalam Menggeneralisasi Pola Linier. Jurnal Nasional Pendidikan Matematika, 4(2), 180-194. https://doi.org/http://dx.doi.org/10.33603/ jnpm.v4i2.3386

Setiawan, Y. E. (2020c). Disposisi Berpikir. CV. Al-Mukmin Yes.

Setiawan, Y. E. (2020d). Pelatihan desain peta konsep menggunakan aplikasi cmaptools. Jurnal PKM: Pengabdian Kepada Masyarakat, 03(04), 395-403. https://doi.org/http://dx.doi.org/ 10.30998/jurnalpkm.v3i4.5567

Setiawan, Y. E. (2020e). The Thinking Process of Students Using Trial and Error Strategies in Generalizing Linear Patterns. Numerical: Jurnal Matematika Dan Pendidikan Matematika, 4(1), 1-12. https://doi.org/https://doi.org/10.25217/numerical.v4i1.839

Setiawan, Y. E. (2021). Kebutuhan Kegiatan Webinar Tentang Disposisi Berpikir. Ethos: Jurnal Penelitian Dan Pengabdian Kepada Masyarakat, 9(2), 288-295. https://doi.org/https://doi.org/10.29313/ethos.v9i2.7651

Setiawan, Y. E. (2020f). Analisis Faktor-Faktor Pendukung Keberhasilan Pelaksanaan Pelatihan Terhadap Guru. Prosiding Konferensi Nasional Pengabdian Kepada Masyarakat: KKN Tematik Untuk Mewujudkan Masyarakat Tangguh Guna Percepatan Pembangunan Di Era Pandemi Covid-19: 7 Desember 2020, 545-557.

Setiawan, Y. E., Purwanto, Parta, I. N., \& Sisworo. (2020). Generalization Strategy of Linear Patterns From Field-Dependent Cognitive Style. Journal on Mathematics Education, 11(1), 77-94. https://doi.org/http://doi.org/10.22342/jme.11.1.9134.77-94

Susantini, E., Rahayu, Y. S., Budiono, D., \& Raharjo, R. (2015). Profil Artikel Ilmiah Buatan Guru Pada Pelatihan Penulisan Karya IImiah Bagi Guru - Guru Di Smp Lab School Surabaya. Jurnal ABDI, 1(1), 1-7. https://doi.org/10.26740/ja.v1n1.p1-7

Sutrisno, S., \& Zuhri, M. S. (2019). PKM Peningkatan Kompetensi Guru Melalui Pelatihan Penulisan Artikel IImiah Penelitian Tindakan Kelas. Journal of Dedicators Community, 3(1), 53-61. https://doi.org/10.34001/jdc.v3i1.793

Tishman, S., \& Andrade, A. (1995). Thinking Dispositions: A review of Current Theories, Practices, and Issues. Harvard University Graduate School of Education.

Tishman, S., Jay, E., \& Perkins, D. N. (1993). Teaching Thinking Dispositions: From Transmission to Enculturation. Theory Into Practice, 32(3), 147-153. 
APPENDIX

Table 1. Webinar Success Category

\begin{tabular}{cll}
\hline $\begin{array}{c}\text { Percentage score } \\
(\mathbf{x})\end{array}$ & \multicolumn{1}{c}{ Category } & \multicolumn{1}{c}{ Information } \\
\hline $0 \% \leq x<20 \%$ & Very Low & Webinar Very Unsuccessful \\
$20 \% \leq x \leq 40 \%$ & Low & Webinar didn't Work \\
$40 \% \leq x<60 \%$ & Currently & Webinar are not successful \\
$60 \% \leq x \leq 80 \%$ & Height & Webinar Was Successful \\
$80 \% \leq x \leq 100 \%$ & Very Hight & Webinar Was Very \\
& & Successful \\
\hline
\end{tabular}

Table 2. Results of Completing the Service Evaluation Questionnaire

\begin{tabular}{llrr}
\hline No. & \multicolumn{1}{c}{ Desciption } & Score & $\%$ \\
\hline 1. & The material is very relevant as l expected & 136 & $80 \%$ \\
2. & The material is well organized and easy to understand & 135 & $79 \%$ \\
3. & The material is sufficient for me to know the theory of thinking disposition & 140 & $82 \%$ \\
4. & Interesting material for me to study it & 142 & $84 \%$ \\
5. & Material is a new thing for me & 138 & $81 \%$ \\
6. & The material improves my understanding of thinking disposition & 140 & $82 \%$ \\
7. & The webinar material is very useful & 148 & $87 \%$ \\
8. & The presenter understands the material presented & 141 & $83 \%$ \\
9. & The presenter's language is easy to understand & 138 & $81 \%$ \\
10. Sufficient time allocation for material delivery & 125 & $74 \%$ \\
11. & The presenter presents the content of the material well & 140 & $82 \%$ \\
12. Confident presenter & 143 & $84 \%$ \\
13. Sufficient time allocation for questions and answers & 132 & $78 \%$ \\
14. The presenter gives correct and good answers & 138 & $81 \%$ \\
15. & Discussions and questions and answers add to my understanding & 135 & $79 \%$ \\
\hline & $\quad$ Score Total & $\mathbf{2 . 0 7 1}$ & $\mathbf{8 1 \%}$ \\
\hline
\end{tabular}

Pemaparan
Materi Tanya Jawab $\begin{gathered}\text { Evaluasi } \\ \text { Pengabdian }\end{gathered}$

Figure 1. Webinar Implementation Stages 


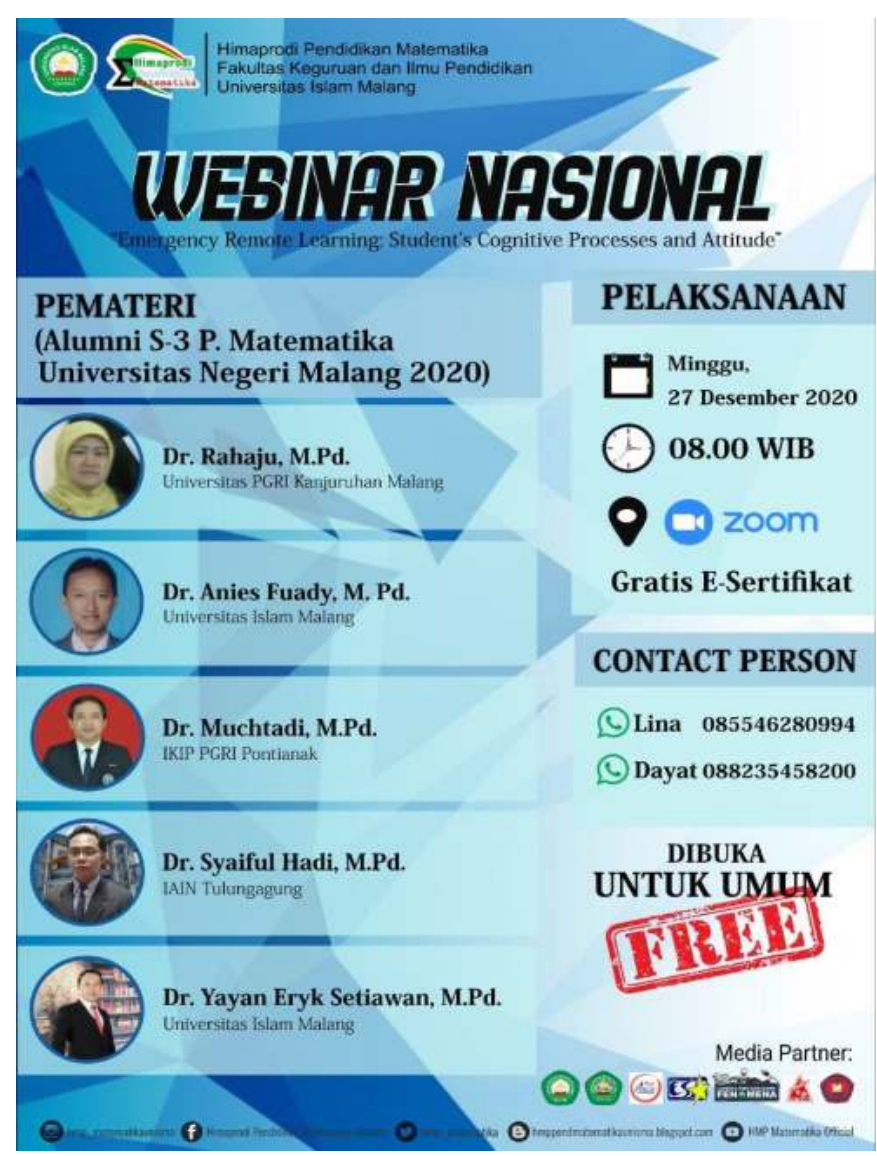

Figure 2. National Webinar Poster

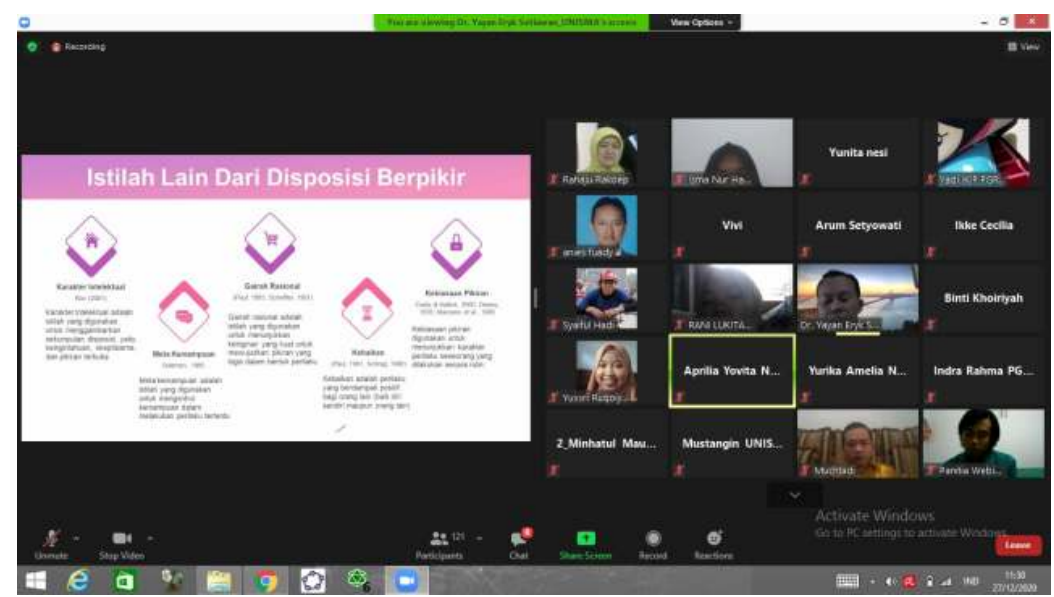

Figure 3. Presentation of Material by Devoted 